\title{
Richard Horton. The COVID-19 Catastrophe: What's gone wrong and how to stop it happening again
}

\section{Polity Press, Cambridge, UK, 2020. pp 133, Paperback \$14.95USD, ISBN-13:978-1-5095-4645-9 and 13:978-1-5095-4645-9 (pb)}

\section{Phyllis Freeman ${ }^{1}\left[\right.$. $\cdot$ Anthony Robbins ${ }^{2}$}

Published online: 17 September 2020

(c) Springer Nature Limited 2020

Locked down at home in London, Richard Horton, long-time Editor in Chief of The Lancet turned his observations and connections with scientists and clinicians around the world to framing a debate. He quickly assembled a book that calls on readers to heed the human fiascos and "complacent exceptionalism" of Western governments that failed to learn from China's experience as COVID-19 approached, then devastated European countries and the United States, among others. As we live through this unparalleled period of "political, economic, and social anxiety and instability" he wants us to jolt our political leaders into cooperating to shape a new epoch in which we are far better prepared to cope. It seems Horton set out to stir up our apprehensions and passions, to get us to articulate the observations underpinning them, argue with him, draw in others, and tackle this mess. Otherwise we risk retreating from the debates about what to transform and how, paralyzed by fear.

He dedicates the book to the many categories of victims whose stories need to illuminate a better way forward, and attributes much of the vulnerability they and their millions of counterparts experience to misguided human attitudes and endeavors, be it racism, lack of esteem for "key" workers, failure to constrain greed in the management of capitalist societies, or faulty systems that do not protect humans from devastating consequences of common social, economic, health exposures.

The book begins with a story of how COVID-19 came to menace Wuhan, and beyond, how and why so many societies reacted inadequately at least or inhumanely and stupidly ("a grubby betrayal" of the "old, sick, and vulnerable"). He sets out

Phyllis Freeman

Phyllis.freeman@umb.edu

Anthony Robbins

Anthony.Robbins@tufts.edu

1 Professor Emerita and co-Editor Emerita, JPHP, University of Massachusetts, Boston, MA, USA

2 Co-Editor Emeritus, JPHP, Tufts University School of Medicine, Boston, MA, USA 
painful consequences of these blunders, along with paradoxical effects of favorable twists (air quality, fewer injuries from vehicle mishaps). Always with an eye on the reshaping of uncertain relationship between COVID-19 and humans from observations of clinicians and early studies, Horton turns to the varied nature of modern nation states, their leadership_or at least reactions to COVID-19, and the combined effects as of May 2020.

Launching into the terms of debate, he ponders: If COVID-19 represents the greatest failure of Western democracies since World War II, what should governments learn from it and how do we need future ones to act? Of course, we must also ask: how do we get them to do so (if and when we figure out the answer to the first question)? One's pessimism can easily be stoked by the egregious examples of the egomaniac bad boys of COVID-19 (our characterization): Donald Trump (USA), Boris Johnson (UK), Jair Messias Bolsonaro (Brazil), Andres Manuel Lopez Obrador (Mexico), to name a few. Or find relief in the far better instincts of some inspiring world leaders, New Zealand's Jacinda Kate Laurell Adern and Germany's Angela Merkel.

Horton catalogues lessons for better preparation for a next pandemic (pp. 85-86; 103 ) - en route to a more philosophic discussion and listing of questions about how humans view the role of societies in handling uncertainty, risk, wealth, knowledge, deprivation, and differences among us in characteristics and values-and how western societies need urgently to find a way to balance "liberty and scrutiny" (think about 'surveillance') in managing their people. The question is how to avoid "the cycle of crisis, harm, action, complacency, neglect, and subsequent vulnerability that followed SARS I 2002-3" (p. 110) that confronts us even more starkly today.

If COVID-19 is to define a new and better epoch, we cannot rely on nation states, especially those that value protectionism over all else. If "COVID-19 brought the world together, then divided it still further" (p. 118) how do we come together, committed to act on our better instincts? Horton envisions the best of changes for societies, governments, publics, medicine, and science. Then sets out a list of profound worries. He imagines a role for the World Health Organization (WHO) beyond the one it has played so far: After declaring a 'Public Health Emergency of International Concern' the WHO could have convened nations in an emergency summit to initiate, lead, and coordinate a global response, based on pooled evidence and experience to mobilize and motivate nations to act quickly and decisively. Although Horton details some of WHO's shortcomings, we add a troubling limitation he did not: not only is WHO a creature of its member states - the players are the Ministers of Health from all those states - those ministries are often the least powerful ones [1]. Given this arrangement, what support and inducements do governments need-and from whom - to lead? Can a UN Secretary General like Antonio Guterres change the dynamics? He noted the COVID-19 induced "tsunami of hate and xenophobia, scapegoating and scaremongering." Is there anything inherent in the world catastrophe of COVID-19 that changes power relations among ministries, within governments, across governments, or the role of multilateral agencies and the United Nations? We'd better renew a concerted debate about these questions.

In the spirit of argument to enliven debate, we want to quibble with Horton. If one is out to engage and change the role of the public, it would seem that a characteristic 
of COVID-19 that he does not mention could be especially important. The Chinese and Italians noticed by March 2020 that not only was COVID-19 transmitted person to person, it seemed to be spreading through asymptomatic carriers-who no one had known could be vectors [2]. At least in the US, confrontations today between those who wear masks and comply with physical distancing guidance and those who refuse to are a troubling part of the modern profile of 'the public'. If we are to heal those divisions along with much else, the revelation about 'community spread' will be well worth reviewing deeply as we reshape a healthier and more collaborative future.

The book ends without mention of what are now several very highly affected regions: for example, Africa, Latin America, the Middle East. Events in these regions intensify and complicate the challenges ahead. Horton focused on the gross negligence of Western democracies, but the stories continue with horrific experiences on which to base more elements of future improvements. Gross negligence or worse has appeared in more places and in more forms. Reports from Uganda, for example, point to a paradox. The country was better prepared than many based on its relatively successful strategy that controlled repeated outbreaks of Ebola. But some Ugandans report that President Museveni misused international aid meant to ward off starvation among a population under a police-patrolled lockdown. Instead of buying and distributing food to those locked away from employment or food, he instead bought vehicles to better mobilize his upcoming campaign for reelection.

So, why should you read this book? Horton set out to provoke us into national conversations about how far each country is prepared to go, and its citizens to pay for, a health system that can better protect the population and save lives-and he has framed it. Towards the end he summarizes catastrophic failures of Western democracies (Chapter 5) and argues that "COVID-19 is not a crisis about health" but "something much worse" (p. 95) - it is about life-and human temptations to "assume omnipotence of our species" (96). He raises philosophic considerations about human societies and offers an optimistic glimpse of how future ones might look if the conversations produce insight, solidarity, and effective transformation. But that depends on whether we can "cultivate our sensibility for intolerance"(p. 117 ) and address a list of worries about what may go wrong (for example, if we lose our capacity to be shocked, detach even further from world affairs, from persistent poverty, inequalities, and allow fear to be our guide).

We need to activate conversations about what we value and how we run societies and manage international relationships in legislative bodies and classrooms, neighborhood meetings and board rooms, in gatherings of scientists and of ministers across sectors in every government. We need to add to those discussions all we learn as COVID-19 damage to people and societies intensifies, disables populations across the globe that are, theoretically, less prepared to cope than the Western democracies - with their economic and many health resources, if not the wisdom nor the will. Since the end of May when Horton's book went to press, the WHO dashboard shows COVID-19 cases reported daily increased from 116,436 on 30 May 2020 to 280, 110 daily on 8 August 2020 as we write [3].

This is a book for all prepared to use our collective experience with COVID-19 and dynamics in our own societies to usher in a "new era of social and political 
relations...in which our liberties will be achieved through new means of cooperation and communication (p. 127). Or, we could just wait for the next pandemic.

\section{References}

1. Robbins A, Freeman P. Is WHO ineffectual because its members are ministries not states? J Public Health Pol. 2015;36:131-3. https://doi.org/10.1057/jphp.2015.4.

2. La Republica. Coronavirus: "Il $50-75 \%$ dei casi a Vo' sono asintomatici. Una formidabile fonte di contagio". https://www.repubblica.it/salute/medicina-e-ricerca/2020/03/16/news/coronaviru S_studio_il_50-75_dei_casi_a_vo_sono_asintomatici_e_molto_contagiosi-251474302/?refresh_ce. Accessed 16 Mar 2020.

3. World Health Organization Dashboard. https://covid19.who.int/. Accessed 9 Aug 2020.

Publisher's Note Springer Nature remains neutral with regard to jurisdictional claims in published maps and institutional affiliations. 